\title{
The Performance Improvement Model of Group and Partnership based Coffee Processing Enterprises in the Jember Regency
}

\author{
Isti Fadah, Handriyono \\ FE Universitas Jember, Indonesia \\ istitatuk@yahoo.co.id
}

\begin{abstract}
The coffee commodity is one of the highly developing world commodities. The increase in demand, production, and consumption shows that this commodity is no longer as a secondary material, but it also has become a compulsory requirement for most societies. The purpose of this study was to determine and analyze alternative marketing strategies for small-scale processed coffee enterprises in Jember regency based on the SWOT analysis. Moroever it was also to determine appropriate strategies in improving the performance of large-scale processed coffee enterprises in Jember regency based on the SWOT analysis and to design marketing strategies for group and partnership based processed coffee enterprises in Jember regency. The research type is a descriptive study. Primary data was collected by indepth interviews. The research results showed cooperation in the form of a co-branding would indirectly introduce community-based coffee from Sidomulyo village to a wider consumer range. Thus, people will recognize that there is a coffee with a distinctive flavor from the Sidomulyo village in Jember regency. The group-based model is by forming a cooperative and the partnership-based model is by forming simultaneous and integrated partnership with the Koka Research Center, PTPN XII, BI, and exporters have both proven to improve the performance of community-based coffee business in Sidomulyo village.
\end{abstract}

Keywords: Model, Business Performance, the Sidomulyo community-based coffee, Group and Partnership Based

\section{Introduction}

Background: The coffee commodity is one of the highly developing world commodities. The increase in demand, production, and consumption shows that the commodity is no longer as a secondary material, but it also has become a compulsory requirement for most societies. Data from the Association of Indonesian Coffee Exporters and Industries noted that the need in 2015 is estimated to rise to 280 million kilograms from the 2014 estimate of 260 million kilograms of coffee in one year. Not only the increase in consumption, rising export demand also shows that coffee has become one of the important current commodities. The Indonesia Statistic Agency recorded that in 2013 there was an increase in the export volumes of green beans, instant coffee, and roasted coffee than in 2012. The increase in export volume clearly showed gradually rising numbers, but not by the commodity value. The coffee price has declined, except for roasted coffee, which is one form of processed coffee that still holds a high value. This shows that coffee producers need to show their development in producing processed coffee. However, the rising consumption of processed coffee and having a high value domestically and internationally were still not enough to provide market opportunities for small-scale coffee farmers, such as the coffee farmers in the Sidomulyo village, Jember regency, East Java.

Coffee farmers from the Sidomulyo village, who called themselves community-based coffee, are still lagging far behind in the sale proceeds value of their coffees. There are many underlying reasons for it, such as lack of human resources capability, inadequate machinery and also unavailable marketing distribution channels. Although the situation has gradually improved and the results of produced coffee are also advanced, the introduction system of processed coffee from this area still needs more conducted. Likewise is the production of processed coffee in the form of instant coffee and roasted coffee which are currently being pioneered by the PTPN XII plantation company located in Jember regency. Processed coffee from both parties, who represent the community-based coffee and the plantation company, is currently undergoing a major competition with its predecessors. Unlike the civet coffee that has become exclusive, because of the limited quantity and producers, the distribution of Arabica and Robusta processed coffee has already been done vastly. Brand names such as Kapal Api, ABC, Goodday, TOP, and others had already entered the market with their instant coffee. Although coffee of both sides, the community-based coffee and plantation company-produced coffee, has its own characteristics and distinctive taste, the conditions of the sale proceeds are still far behind those of some well-known brands. 
The marketing conditions of community-based coffee are currently only limited to the business outlets located in cooperatives in the Sidomulyo village. This coffee has not yet found a market and marketing distribution channel, other than waiting for buyers who come to their area. The regional condition, which cannot be considered appealing to visit, causes the sale of processed coffee not as expected. Thus until now, the choice is to wait for buyers, such as researchers and small-scale coffee lovers who has become loyal customers. The existing condition is not much different than as experienced by plantation companies for other than green bean processed coffee products. Although at least their sales proceeds are higher than the community-based coffee producers, the sale proceeds are still too low compared to the performance results of the green bean, which became their main product. The current marketing carried out by plantation companies is through outlets and cafés that they manage. However, the management on one of the cafés that is still not considered seriously causes the marketing of processed coffee products other than green bean to be undeveloped. Even though the PTPN XII name is well known, but the processed coffee products besides the green bean coffee from this company still cannot penetrate the market in general. The management strategies of processed coffee at both industries need special attention. In addition to raising the economic level of the industry, it will also contribute to the national economy. The strategies that may be applied are to provide a way for both industries to cooperate or form partnership. Therefore, with the advantages from both industries, the processed coffee products can be further recognized by vast societies.

\section{Research Objectives}

- To identify and analyze alternative marketing strategies for small scale processed coffee products in Jember regency based on the SWOT analysis.

- To identify and determine appropriate strategies to improve the performance of large-scale processed coffee enterprises in Jember regency based on the SWOT analysis.

- To identify, analyze and design marketing strategies for group and partnership based processed coffee enterprises in Jember regency.

\section{Literature Review}

Co-branding Strategy: Co-branding is one of the brand establishment strategies that have been widely used in modern business cooperation. Many well-known companies have applied it, such as the SmartFren brand. Kotler (2005) stated that co-branding is two or more well-known brands combined into one major brand, or two or more companies create a joint brand to distribute or sell goods. While Lamb \& McDaneil (2001: 429) mentioned that co-branding is the establishment of two or more brand names on its product or its packaging. There are several kinds of co-branding according to Kotler (2005), such as follow:

- Component co-branding is where a company creates a product where one company makes the product and adds one of the product components of other companies that are already established and well-known quality. The example is when the Volvo car advertises that its car tires are from Michelin.

- Some-company co-branding is where the same or similar companies does co-branding to reduce competition and to control the market.

- Joint venture co-branding is when two companies are engaged in the same field conduct a joint venture not only on one type of product but in all activities of the company.

- Multi-sponsors co-branding is when more than two companies merged to form a single product with a joint brand.

Surachman (2008: 125) mentions that co-branding has its advantages and disadvantages as explained bellow.

\section{Advantages}

a. The offers that were made can cover two or more sources of similar brand, so that it strengthens the sale purpose, value, and differentiation.

b. Can generate more sales from existing target markets and also open up additional opportunities for new consumers and channels.

c. Reduce the cost of launching a product, because it combines two well-known images and accelerate adoption.

d. Can be a valuable source for studying consumers and for how other companies approach them. 


\section{Disadvantages}

a. Potential disadvantage of co-branding is the risks and the lack of control to connect with other brands in the minds of consumers. Consumer expectations on the level of joint brand involvement and commitment will be high, so that any unsatisfactory performance can provide a direct negative impact for both brands. If other brands are included in several co-branding arrangement, excessive exposure may dilute the transferring of each association.

b. Co-branding can lead to lack of focus on existing brands.

Marketing Channel: Walter (1977) in Basu Swastha (1981) mentions the marketing channel is a group of traders and agents that combine the physical displacement and the name of a product to create usability for certain markets. While Kotler explains that there are two strategies applied in marketing channels, such as push strategy and pull strategy.

Push Strategy: Push strategy is basically trying to persuade intermediaries to want to market their products by providing certain facilities. For example, a high discount when purchasing the product. This strategy is suitable for products with low loyalty and when marketing a new product with limited production, so it tries to use experienced marketing channels in marketing various products.

Pull Strategy: Pull strategy is basically the producers who employ advertising and media to persuade consumers to ask intermediaries, so that it will attract the intermediary to make a purchase. This strategy is suitable with high brand loyalty, so that consumers play a role in sales.

Tourism Village: Nuryanti (1993) mentions the tourism village is a form of integration between attractions, accommodation and supporting facilities presented in a societal living structure that integrates with the prevailing procedures and traditions. There are two existing concept forms of tourism village, namely in the form of attractions and accommodation. The attraction form is a form of tourism village where the daily lives of the villagers becomes a material that can be directly integrated towards existing communities, such as classes in dancing, language, direct agricultural learning, and etc. Meanwhile, the accommodation form is a tourism form, which is aimed at staying in a few villagers' living places or units that are developed on the basic concept of residence. According to the UNDP/WTO and Indonesian travel consultants, there are two approaches that can be done to develop a village into a tourism village, such as the market approach and the physical approach.

a. The Market Approach: In the market approach, there are three interactions that can be used to develop a tourism village, namely:

Indirect Interaction: Indirect interaction is a development model that is approached by creating villages to achieve benefit without direct interaction with tourists. One example of the way is to make a book about the state of the growing village, its history, its traditional architecture, and so forth.

Semi-Direct Interaction: Semi-direct interaction can be shown by a one-day trip activity. On this trip, the concept is activities carried out by the tourists with the villagers for one day without staying in the village. Direct Interaction: In direct interaction, tourists directly experience the village life by living in the villagers' homes for several days, and they do all the activities they want to do with the villagers.

b. The Physical Approach: Physical approach is an approach that is generally done in developing a village through the tourism sector. Physical approach can be done in several ways, including:

- Conserving several houses that have high cultural and architectural values and alter the function of the residence into a village museum to produce the caretaking costs.

- Conserving the entire village and provide new land to accommodate the development of the rural population and at the same time develop the land as a tourism area with tourism facilities.

- Developing accommodation forms in the rural areas as small-scale industries.

\section{Methodology}

In this research, the object was the two groups of processed coffee enterprises, namely the small-scale and large-scale processed coffee business groups in Jember regency. The data collection by means of indepth interview, and information investigation is through focus group discussion (FGD) to find a more holistic and comprehensive phenomenon. The basic methods used in this research are descriptive, comparative and correlational methods which produce a general overview of the actual problem solving that currently exists. A descriptive analysis approach is used in order to achieve the first and second goals of the in this study, which are: (a) to determine and identify potential maps of small scale and large scale 
processed coffee enterprises in Jember regency, and (b) to identify and analyze which basic problems they faced by processed coffee enterprises in Jember regency, and also why it occurred and identify alternative solutions. Descriptive analysis was applied not in order to test the hypothesis, but to illustrate the reality of the environment. Descriptive analysis approach is a troubleshooting procedure which is investigated by describing research subject/object of the present research based on the existing facts or as it is.

SWOT Interaction Analysis: In order to achieve the objectives in this research, namely: "To know and analyze alternative marketing strategies of small scale processed coffee enterprises in Jember regency based on SWOT analysis" and "To identify and determine appropriate strategies to improve the performance of large-scale processed coffee enterprises in Jember regency based on SWOT analysis", the SWOT interaction analysis approach was applied. The first step in this series of analysis is to firstly identify the key internal and external factors surrounding the processed coffee enterprises. Key internal factors include (a) strengths and (b) weaknesses within the presence scope of processed coffee business in Jember regency. Key external factors include (a) opportunities and (b) threats. The second step is to compile an internal factor (EFI) and external factor (EFE) evaluation matrixes. The filling of the internal factor evaluation matrix (EFI) can be described as follow (David, 2002):

a. In the key internal factor column contains the critical success factors which are identified in the internal evaluation process (internal audit).

b. In the problem burden column contains the burden value rank key towards identified key internal factors, with a value range from 0.00 (unimportant) to 1.00 (important /most important).

c. The sum of all burdens $(\mathrm{P} 1+\mathrm{P} 2)$ on the problem burden column must be equal to 1.00 .

d. The problem urgency column indicates whether the key internal factors that represents: (a) the main weaknesses (rank = 1), (b) small weaknesses (rank = 2), (c) small strength (rank = 3), and (d) main strength (rank $=4$ ).

e. In the burdened value column is the result of multiplying the problem burden with the problem urgency of each identified key internal factors.

f. No matter how many key internal factors that are entered into the EFI matrix, the burdened total value can range from the lowest 1.00 to the highest 4.00 , with an average of 2.5 .

The third step is to formulate a SWOT interaction grand strategy. As expressed by Susilo (2000), the SWOT interaction grand strategy analysis is basically an interaction from the analysis results of internal (EFI) and external (EFE) factors evaluations. SWOT interaction grand strategy is a systematic way to formulate alternative strategies that illustrate the best match among other analyzes (Salusu, 2000). If the SWOT interaction grand strategy analysis is applied accurately, this simple assumption has a huge impact on the design of a successful strategy (Susilo, 2000). The existence of chosen alternative strategy is positioned in one of the 4 (four) quadrant selected strategies (positioning strategy) on grand strategy matrix, namely (David, 2002: 131): (a) So strategy, (b) WO strategy, (c) ST strategy, and (d) WT strategy. In order to determine the selected strategy, the burdened value results will be used from the IFI matrix and IFE matrix. Selected strategies can be determined from the sum of the burdened total value with the highest value.

\section{Results and Discussion}

Management Strategy Design of Group and Partnership Based Processed Coffee Enterprises: Referring to the needs of each business group, small scale (Ketakasi cooperative) and large scale (PTPN XII), a mutual and beneficial relationship can be established between the two sides. This is done as a strategy to provide greater opportunities to the sale value of the processed coffee production, so that it can be profitable to each party. The management strategy design of group and partnership based enterprises generally consists of five important internal relationship positions, which are:

Individual to Group: The coffee plantations in the Sidomulyo village are not owned by business groups, but by individuals who cultivate their own land. Coffee management by individuals has many disadvantages and ineffective to become a cooperation basis, because besides the too small scale, the management system would be too difficult to implement. This is what underlies the individuals must create business groups, such as cooperatives or other community groups, in order to facilitate partnership with large companies. 
Group to Company: One of the main problems from the coffee business performance in the Sidomulyo Village is non-ongoing optimal marketing activities of their products. Areas, which are not well known, become a limitation of the existing marketing. Even though coffee from Sidomulyo is quite famous for coffee observers, but among the vast society, this coffee is still unable to compete with the coffee from company-owned plantation such as PTPN XII and other private companies. Therefore, cooperation is necessary by cooperating with the larger business groups and has a brand name to open marketing channels. The cooperation between groups in the Sidomulyo village currently had only limitedly sell green beans to companies who are lacking in production, so there are no long-term and short-term cooperation plans. Co-branding is one form of cooperation that can be done by both sides, which will produce a new product on behalf of plantation company and Sidomulyo village.

There are three types of coffee currently being able to produce by both parties, namely green bean, instant coffee and roasted coffee. Green bean is the product with the highest sales capacity. Unlike the processed form of roasted coffee and instant coffee that cannot compete with other instant coffee, the green bean has acquired loyal consumers in some foreign countries. As the initial stage of cooperation, the introduction of coffee products from Sidomulyo village is the main thing that needs to be done. The main product of green bean is the released opening product before the introduction of processed coffee, such as instant and roasted coffees. Prioritizing green bean products is basically because the processing development of the material will be easier than processed and instant coffees. This processing would cause its own characteristics towards coffee originally processed by Sidomulyo village, and also coffee originally processed by PTPN XII. After successfully bringing the Sidomulyo village name, co-branding business development continues to the other types of processed coffee. This initial means is to utilize already-owned facilities by business groups and companies, such as café outlets and cooperatives.

Group to Buyer: Sidomulyo village, which is famous for its delicious coffee, must have its own focus and distinctive characteristics towards its processed coffee products. Although in the early stages the consumer target of coffee is still far from expected, but slowly with indirect promotions attached to the co-branding partnership will begin to open the marketing on processed coffee. Sidomulyo village needs to be often promoted as a famous coffee tourist spot. Cooperation with the Jember Department of Tourism and actively promoting the coffee through available media such as social networking, village websites, or coffee competition as previously carried out.

Company to Buyer: Consumers faced by the company are more focused on large scales. Coffee exports as well as becoming a coffee supplier for large companies with an established brand becomes the source that will bring great opportunities. Nevertheless, it is possible for plantation company to open its own outlets to market their instant coffee that has added value. With the cooperation between companies and the Sidomulyo village business groups, the company will have more coffee varieties with different quality and characteristic levels. Thus, in the future, it will expand various market shares.

Stakeholders and Researchers with the Group and Company: This relationship becomes a kind of coordination activity between the developers and financiers. The developers who are from research centers, educational institutions, and other parties will assist the development of business activities toward better improvement. The threat of fraud on cooperation between companies and Sidomulyo village business groups will be minimized as long as the business group as the weaker party receives support from the developers. The financiers are nothing more than the investors who want to invest in the coffee business in the Sidomulyo village. With the further development of coffee plantation, it is possible that investors will enter with funds that would make the quality of the coffee business in the Sidomulyo village better.

SWOT Analysis on the Management Strategy Design of Group and Partnership Based Processed Coffee Enterprises: In analyzing the formulated design strategy, the SWOT analysis is used as the material to view the strength and weakness of the created model. So that there can be reparations and solutions for existing models.

\section{Strength:}

- Cooperation in the form of a co-branding will indirectly introduce coffee from Sidomulyo village people to a wider community. Therefore, people will recognize there is coffee with a distinctive taste from the Sidomulyo village in Jember regency. 
- Additional production number from Sidomulyo Village will open greater export opportunities for the company. The increasing varieties of coffee quality could become better or worse that can affect the price, but it will also provide new markets for the company.

\section{Weakness:}

- Marketing for roasted and ground processed coffee is still a weakness for both parties, i.e. the plantation company and the Sidomulyo village, thus that type of processed coffee will become cooperation product only in small amount.

- With the cooperation, the plantation company has a greater burden to market the co-branded products, because the plantation company has more brand names compared to the group. If there is no development plan, the marketing of existing products will fail.

Figure 1: The Management Strategy Design of Group and Partnership based Processed Coffee Enterprises

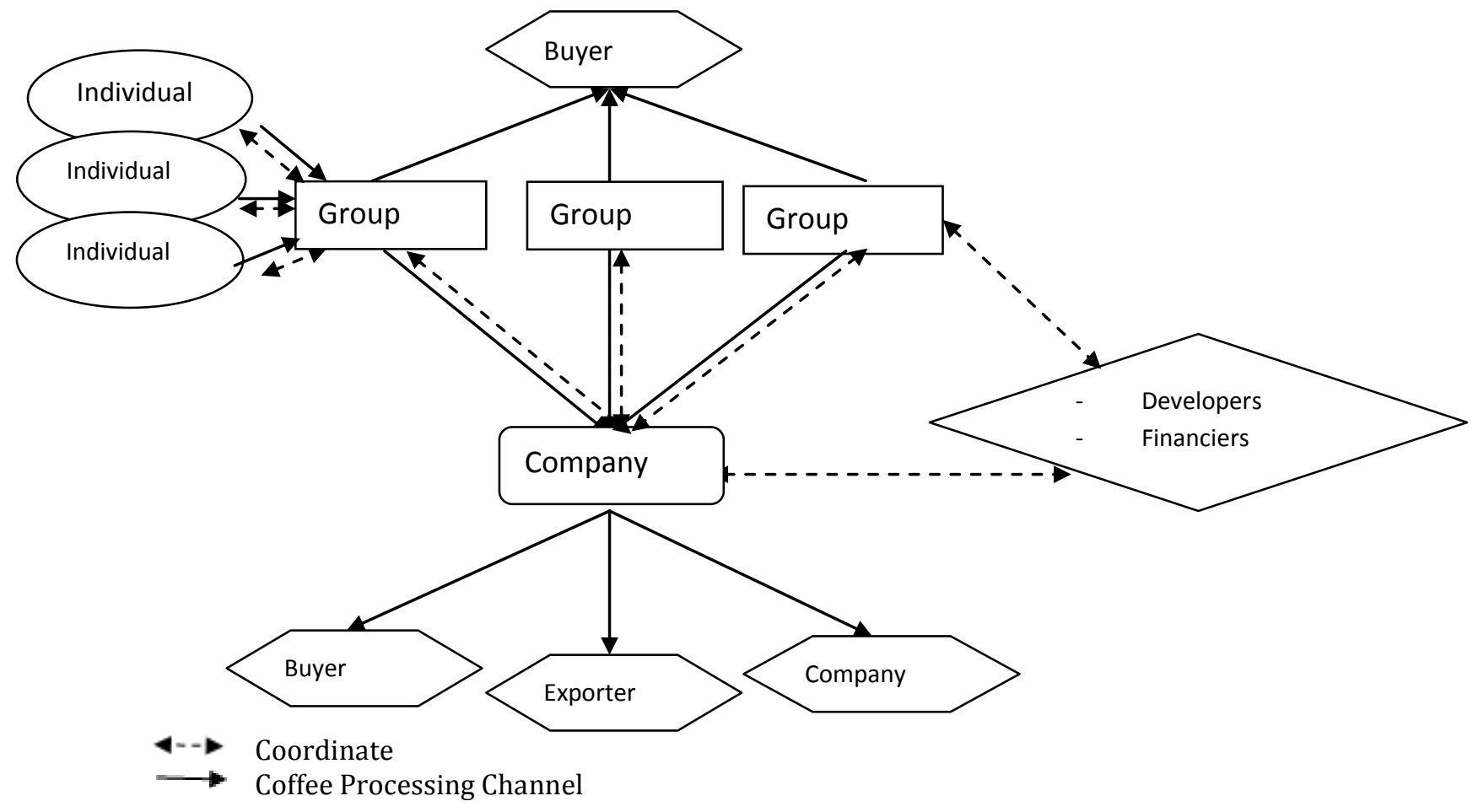

Table 1: SWOT Analysis for Strategy Model

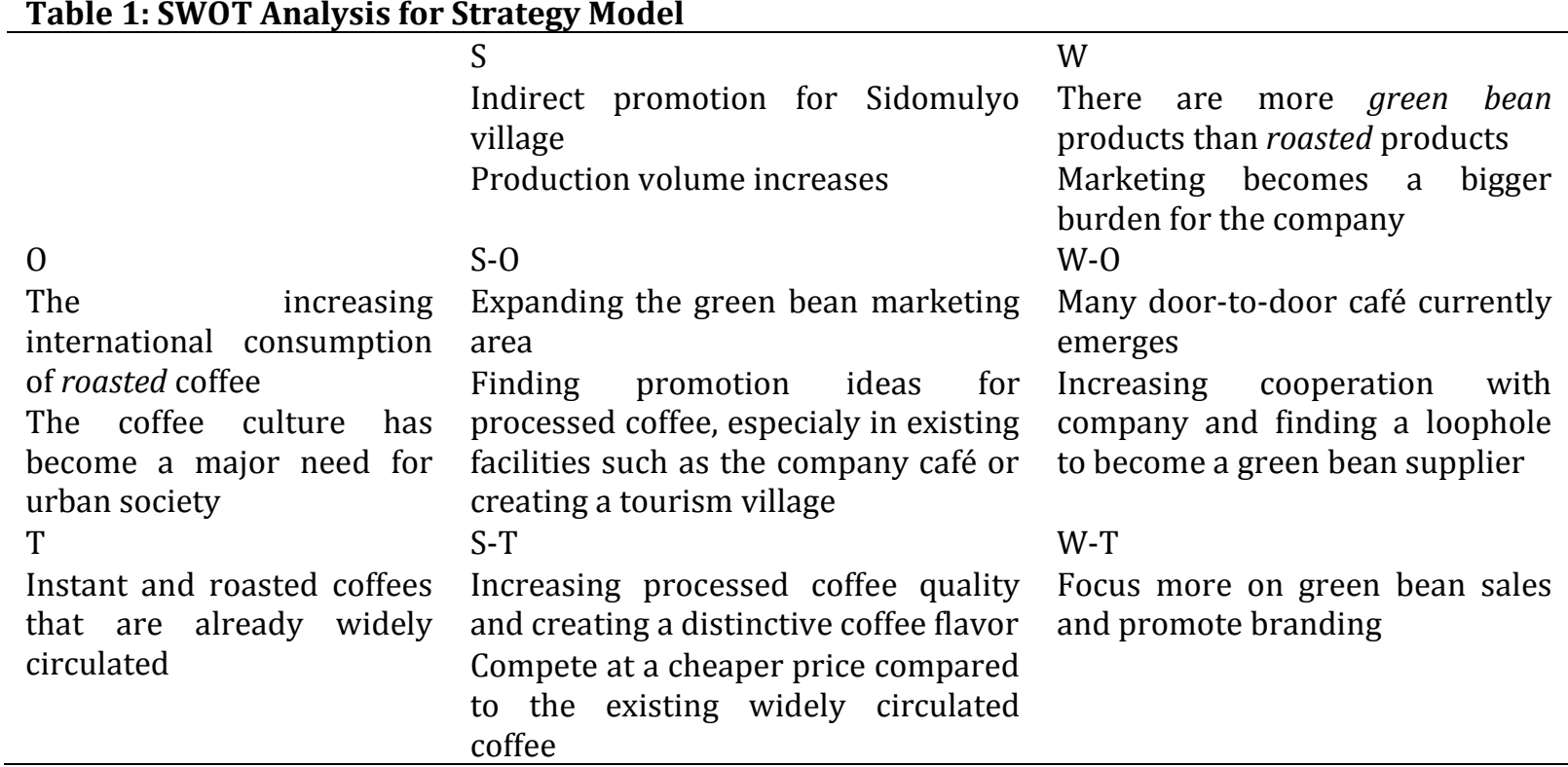




\section{Opportunity:}

- The increased international and domestic coffee consumptions provide definite opportunities for the company to expand its market share. Not only the green bean products, but also (roasted) processed coffee products have the opportunity to thrive.

- Urban culture that has began to enjoy coffee as daily need provides high opportunity to market the existing coffee, mainly from the co-branding processed coffee.

- Sales of coffee machines has recently increased sharply, which shows that people will buy more processed form of roasted coffee rather than instant coffee.

\section{Threat:}

- There are many instant coffee which are widely circulated and have had brand name is still a strong threat to the new processed coffee products of co-branding.

\section{Conclusion and Recommendation}

Strength: Cooperation in the form of co-branding between community-based coffee and plantation companies (such as PTPN XII) will indirectly introduce the Sidomulyo village community-based coffee to a wider community. Therefore, the wide community will recognize that there is a coffee with a distinctive flavor from the Sidomulyo village, Jember regency.

Weakness: Marketing for roasted and powdered processed coffees are still a weakness of both parties, namely the plantation company and Sidomulyo village, thus that type of processed coffee becomes a cooperation product only in small number. With that cooperation, the company has a greater burden to market the co-branded products, because the company has more brand name than the group. If there is no development plan, the marketing of existing products will fail.

Opportunity: The rising international and domestic coffee consumptions provide definite opportunities for the plantation company to expand its market share. Not only the green bean products, but (roasted) processed coffee products also have the opportunity to thrive. The urban culture has started to enjoy coffee as a daily need provide a high opportunity to market existing coffee products, particularly processed coffee of co-branding.

Threat: The instant coffee that has been widely circulated and has brand name is still a strong threat to the new processed coffee products of co-branding.

Referring to the diagnosis results of the internal environment that produces the strengths and weaknesses analysis, and the diagnosis results of the external environment that generates opportunities and threats analysis, thus developments of the group-based model by forming a cooperative and a simultaneous and integrated partnership-based model between community-based coffee with the Koka Research Center, PTPN XII, BI, and exporters are a new energy and new expectations, as well as it has shown to improve the performance of community-based coffee in the Sidomulyo village.

Suggestion: Community-based coffee entrepreneurs should constantly innovate products, seek to improve cooperation with academic institutions in the form of aiding coffee processing machinery, and establish cooperation with the academic experts in order to improve the human resources quality. Largescale coffee entrepreneurs, namely the PTPN XII should continuously expand the target market for green bean, increase sales of ground coffee by redesigning the cafe into a more attractive place and a more strategic position, and finally cooperating with existing cafes in Jember regency.

\section{References}

Basu, S. (1981). Manajemen Pemasaran Modern, Yogyakarta : Liberty.

David, P. N. (2002). Balanced Score Card, Menerapkan Strategi Menjadi Aksi, Terjemahan Herman Wibowo, Erlangga Jakarta

Kotler, P. (2005). Manajemen Pemasaran. Alih Bahasa Oleh Hendra Teguh, Ronny A Rusly, Benjamin Molan, Edisi Milenium, and Jakarta : PT Prenhalindo.

Lamb, H. \& McDaniel, D. (2001). Pemasaran. Jakarta : PT Salemba Empat.

Nuryanti, W. (1993). Concept Perspective and Challengers, Makalah dari Bagian Laporan Konferensi Internasional Mengenai Pariwisata Budaya. Yogyakarta. Gadjah Mada Press

Salusu, J. (2000). Pengambilan Keputusan Strategik : Untuk Organisasi Publik dan Organisasi Non Profit, Jakarta : PT Gramedia Pustaka Utama.

Surachman, L. (2008). Dasar-dasar Manajemen Merek. Malang: Bayu Media Publishing

Susilo, M. (2000). Sumber Daya Manusia dan Produktivitas Kerja, Cetakan Kelima, Bandung: Bina Aksara 